\title{
Gastric Cancer pT2 TNM Finding v8
}

National Cancer Institute

\section{Source}

National Cancer Institute. Gastric CancerpT2 TNM Finding v8. NCI Thesaurus. Code C133612.

Gastric cancer with tumor invading the muscularis propria. A tumor may penetrate the muscularis propria with extension into the gastrocolic or gastrohepatic ligaments, or into the greater or lesser omentum, without perforation of the visceral peritoneum covering these structures. In this case, the tumor is classified as T3. If there is perforation of the visceral peritoneum covering the gastric ligaments or the omentum, the tumor should be classified as T4. (from AJCC 8th Ed.) 